Available online at

\title{
Measurement Of Occupational Safety And Health Risk Levels Of Kadiri University LP3M Building
}

\author{
S. Susanto ${ }^{1 *}$, Hendy ${ }^{2}$, Sumargono ${ }^{3}$, B. Winarno ${ }^{4}$, A. I. Candra ${ }^{5}$. \\ ${ }^{1 * 2,3,4,5 .}$ Faculty of Engineering, Kadiri University \\ Email : ${ }^{1 *}$ sonysusanto@unik-kediri.ac.id
}

\begin{tabular}{|c|c|}
\hline Article History : & \\
\hline Article entry : & : 25-03-2020 \\
\hline Article revised & : 04-04-2020 \\
\hline Article received : & : 07-04-2020 \\
\hline
\end{tabular}

Keywords :

Identification, Risk assessment, Questionnaire, Matrix.

IEEE Style in citing this article : [21] G. Rong, W. Sainan, and H. Mengshi, "Underground railway safety analysis and planning strategy: a case of Harbin metro line 1 , China," Procedia Eng., vol. 165, pp. 575-582, 2016, doi: $10.1016 /$ j.proeng.2016.11.753.

\section{A B S T R A C T}

Construction work for high rise buildings is a dense work activity with a high level of risk. The purpose of this research is that construction of the building takes place in the middle of lecture activities where many students, lecturers, and staff carry out activities in the campus environment, considering that construction projects are generally vulnerable to work accidents. This study investigated the identification, K3 risk assessment, and how to control OHS risks in Kadiri University LP3M building projects. The assessment method uses a matrix sourced from AS / NZS 4360: 2004. The study population numbered 58 workers ranging from workers, artisans, project guards, forepersons, executors, and office staff. The sample in this study amounted to 38 respondents. Data collected from questionnaires to respondents. The results of the study showed that immovable/ tripped objects with a risk index of 20 included a very high-risk classification, high-risk classification of 4 variables, classification at medium risk level as many as ten variables can endanger workers and jobs while classification at a low-risk level as much as two variables.

\section{Introduction}

Increased development of various regions in Indonesia in the field of construction consists of the upper structure. The lower structure makes many contractors competing for $\mathrm{d}$ natural executing a project at the start of speed, quality, and cost [1]. However, many contractors override Occupational Health and Safety (K3) in construction projects [2]. Work accidents that occur in a construction project will be one of the causes of disruption or cessation of project work activities [3][4]. The construction work of building multi-story is a job solid with the risk level high [5].

The construction process of building construction projects is generally an activity that contains a lot of hazardous elements [6]. There are many potential hazards in the 
workplace and result in losses to all parties concerned. Prevention efforts that can be done include applying the concept of occupational safety and health (K3) [7]. Development was done with simple or high-tech, never escape from the risk of accidents. This risk can be seen from the quality of human resources in the project location. Every year around the world, 2 million people die from work-related problems [8]. In 2010, there were 65,000 work accidents, 1,965 workers died, 3,662 workers had functional disabilities, 2,713 partial disabilities, 31 total disabilities, and the rest can be cured [7].

In Indonesia, according to data from the Ministry of Manpower and Transmigration (Kemenakertrans), the number of work accidents as of the fourth quarter of 2014 shows that there are 14,519 cases of work accidents. In general, the occupational safety and health (K3) rates of companies in Indonesia are still low [5]. Therefore implementing occupational safety and health management (K3) is very important because it aims to provide a pleasant, comfortable, and safe working environment and conditions [8]. But all government efforts will not succeed without a response from companies and workers to address problems or violations of occupational safety and health (K3). Various control efforts need to be made to minimize work accidents by implementing K3 risk management (safety and occupational health) [9].

According to the 2018 Indonesian Higher Education Statistics data, the East Java region has 137 private universities, one of which is Kadiri University [10]. The University of Kadiri is one of the private universities in Ko ta Kediri who are doing. Development of educational facilities to create a comfortable and conducive atmosphere for lectures. Located Kadiri University on Jl. Selomangleng No. 1 Kediri City. The construction is being done in the development of the LP3M lecture building. This building has a size of $15 \mathrm{~m} 16 \mathrm{~m}$, the height of the building three floors with the number of workers who involved around 58 people.

Building a story ongoing on campus need to pay more attention because construction of the building took place amid lectures where many students, faculty, and staff who perform activities in area campus, considering the construction projects are generally susceptible to a work accident. One thing to note is that the aspects of the implementation of the Occupational Health and Safety are a process identified and risk measurement and management of the risk of occupational safety and health to facilitate the contractor in making control or treatment of existing threats to minimize the number of accidents on the job and also work dap at performing well, in terms of human resources (HR) and duration of the implementation of the 
work. Still, it can create the conditions area a safe and comfortable working. Based on problems that have described the background, the problem formulations discussed in this study are as follows :

1. How to identify and provide an occupational safety and health (K3) risk assessment in the Kadiri University LP3M building project?.

2. How to handle occupational safety and health (K3) risks in the Kadiri University LP3M building project?.

Objectives achieved research I ni to identify and assess each risk and control measures against the risk of Occupational Health and Safety (K3), which occurred in a building LP3M University of Kadiri. The method used in this study is a matrix method [11].

\section{Literature Review}

As a scientific work, research must be based on influential theories and come from reliable sources [12] of which will be discussed in the following chapter.

\subsection{Risk Management.}

Risk is something that leads to the uncertainty of an event's occurrence during a specific period that causes losses, be it small or significant losses, which affect the profitability of a company [13]. The losses feed uncertainty forms should be understood adequately by the organization as part of the strategy to be an added value and support the achievement of organizational goals [14]. Risk management is the activity of planning, organizing, directing, and controlling the company's corporate resources to achieve specific objectives within a particular time with certain resources [5].

\subsection{Occupational Health and Safety Risk Management (K3).}

Good work is a state secure and safe from suffering in carrying out its action [15]. Healthy's work is a condition free from the physical and emotional disease [16]. Based on the description above, occupational safety and health are vital for the company, because the impact of accidents and occupational diseases is not only detrimental to employees, but also the company, either directly or indirectly.

Occupational Safety and Health (K3) Risk Management is an effort to manage risks to prevent unwanted accidents in a comprehensive, planned, and structured manner in a good friend's team [17]. 


\subsection{Identification of Risk.}

Risk identification is a series of processes for carefully identifying the risks and risk components inherent in activities or transactions directed to measuring and managing risks correctly [18]. The stages in risk management include planning, assessment (identification and analysis), handling, and risk monitoring.

\subsection{Measurement of Risk.}

Measurement/Assessment risk is to determine the level of risk based on the identification of the hazard that has been done. Measurement is vital to evaluate whether risk acceptable or not because it affects the whole program in the management of risk [19].

\subsection{Avoiding Risks.}

This method is done by not doing activities that present risks if the project can be done by changing the project plan to balustrades risk. Although not all risks can be avoided, some risks may be avoided [20]. Some of the risks that may occur in the early stages of the project can be avoided by clarifying the project requirements (requirement), collecting information, improving communication, or repairing inability. Maybe this way bi s a seen as a way to deal with all the risks. But keep in mind that avoiding danger also means eliminating the chance profit potential [21].

\section{Research Methods}

\subsection{Population.}

The population is a generalization area consisting of objects or subjects with specific qualities and characteristics determined by researchers to study and then draw conclusions [22]. The community in this study were all employees are housed in the project Building LP3M University of Kadiri.

\subsection{Samples.}

The sample is part of the number and characteristics possessed by the population to be investigated. It considered being representative of the entire population [22]. In determining the number of samples, this study uses a probability technique using random sampling, namely the sample selection method. Each member of the population has an equal chance of being selected as a sample member. The sample size in this study used the Slovin ruin [23]. 


$$
\begin{aligned}
& n=\frac{N}{1+\left(N e^{2}\right)} \\
& n=\frac{58}{1+\left(58 \times 0,1^{2}\right)}=\frac{58}{0,58+1}=37,71
\end{aligned}
$$

Based on the above calculations, the authors complete the number of samples to 38 samples. Information :

$\mathrm{n} \quad=$ Sample size/number of respondents.

$\mathrm{N}=$ Population size.

$\mathrm{e} \quad=$ Percentage of all allowances accuracy samples are still tolerated $(1 \%, 5 \%$, and $10 \%)$.

\subsection{Data Collection Techniques.}

The value needs to be processed to produce information or information in the form of facts [24]. The data collection technique used in this study was a questionnaire. The questionnaire is a collection of data. It makes a list of questions asked to respondents who have been determined as samples [25]. The survey in this study's measurement is the K3 risk variable to assess the impact of the risk level.

\subsection{Research Instruments.}

A research instrument is a tool used to measure the observed phenomenon [23]. In this study, the authors will use an application program computer, namely software SPSS (Statistical Product and Service Solution) Statistics 25. The application program computer will be used by the authoring software to analyze test validity and test reliability.

1. Validity Test.

The validity test is used to measure whether a questionnaire is valid or not. Test the validity of the instrument in this study using the Pearson Product Moment formula [26] :

$$
R_{x y}=\frac{N \sum X Y-\left(\sum X\right)\left(\sum Y\right)}{\sqrt{\left\{N \sum X^{2}-\left(\sum X^{2}\right)\right\}\left\{N \sum Y^{2}-\left(\sum Y\right)^{2}\right\}}}
$$

Information :

Rxy $=$ Grain correlation coefficient. $\quad \sum Y=$ Total score of all items respondents.

$\sum \mathrm{X}=$ Total score for each item. $\quad \mathrm{N}=$ Number of Samples.

The validity test is done by comparing the calculated $r_{\text {value }}$ with the $r_{\text {table. }}$. If $r_{\text {count }}>$

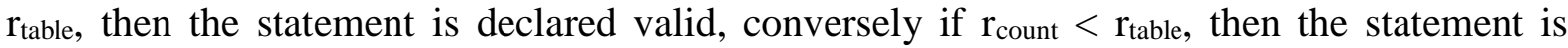
declared invalid [16]. 
2. Reliability Test.

The reliability test is a measure of respondents' stability and consistency in answering matters relating to questions on a variable. Determining whether a research instrument is reliable can be seen from the Cronbach's alpha and $r$ table values. Suppose the value of Cronbach's Alpha> $r$ table. In that case, the research instrument is said to be reliable, meaning that the measuring device used is correct. The reliability of a variable construct is said to be good if it has a Cronbach's alpha value greater than 0.600 [16].

With the formula :

$$
R_{11}=\left(-\frac{k}{(k-1)}\right)\left(1-\frac{\sum \sigma b^{2}}{\sigma^{2} t}\right)
$$

Remarks :

$\mathrm{R} 11=$ Reliability Coefficient. $\quad \sigma^{2} \mathrm{t}=$ Number of grain variants.

$\sum \sigma b^{2}=$ Total variance. $\quad \mathrm{k}=$ Number of questions.

\subsection{Data Analyst.}

One of the ways that are often used to perform analysis and risk assessment is to use a matrix method. Through these methods, first, determine risk factors, then connected with the process to be completed. The following elements characterize project risk :

a. Risk events show the negative impacts that can occur on the project.

b. Pro availability of events.

c. Impact of the risk.

Total weight the negative impact of (a) above is equal to the probability of occurrence even (b) multiplied by the depth of the effect that occurred (c). One way I am by the matrix method with the following steps :

a. Determine the risk events to be analyzed, such as delays in the completion of a job schedule.

b. Here studied the probability of occurrence of a delay in step pert ama, air- like methods can be used for this purpose will be described below.

c. Analyzed and assessed the impact of risks that arise, namely by estimating the criticality and weight.

d. Has examined the probability of occurrence of the depth of the effect and importance, then the next plan, or determines responses in need, for example, Kotijensi or insurance cover for insurable risk. 
e. The final stage is a look, and corrective action when implementing response deviates from the planning [26].

The Probability Impact Matrix is an approach developed using two essential criteria to measure the risk index. The risk index is the multiplication of the probability score and the impact score obtained from the respondent. For determining the level of risk in a way analysis or variable rate risk using risk index after it was input into the matrix. The risk index can use the formula [6]:

$$
\begin{gathered}
\text { Opportunity Average }=\frac{\sum_{1}^{n} \text { Opportunity }}{\text { Respondents }(n)} \\
\text { Impact Average }=\frac{\sum_{1}^{n} \text { Impact }}{\text { Respondents }(n)} \\
\text { Risk Index }=\frac{\sum_{1}^{n} \text { Opportunity } x \text { Impact }}{\text { Respondents }(n)}
\end{gathered}
$$

\begin{tabular}{|c|c|c|c|c|c|}
\hline Severity & Negligible (1) & Minor (2) & Moderate (3) & Major (4) & Extreme (5) \\
\hline Rare (1) & Low $(1 \times 1)$ & Low (1x2) & Low $(1 \times 3)$ & Low $(1 \times 4)$ & Medium (1×5) \\
\hline Unlikely (2) & Low $(2 \times 1)$ & Low (2x2) & Medium (2×3) & Medium $(2 \times 4)$ & High $(2 \times 5)$ \\
\hline Possible (3) & Low $(3 \times 1)$ & Medium (3×2) & Medium (3×3) & High (3x4) & High $(3 \times 5)$ \\
\hline Likely (4) & Medium (4x1) & Medium (4×2) & High $(4 \times 3)$ & High $(4 \times 4)$ & Very High (4×5) \\
\hline Almost Certain (5) & Medium (5x1) & High (5×2) & High $(5 \times 3)$ & Very High (5x4) & Very High (5×5) \\
\hline \multicolumn{6}{|c|}{ Adapted from the AS/NZ 4630 Standard Risk Matrix and NHS QIS Risk Matrix } \\
\hline \multicolumn{6}{|c|}{ 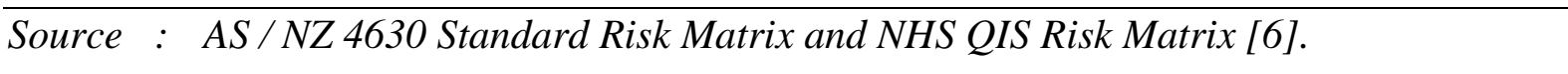 } \\
\hline Very High Risk & : Very high ris & & Medium Risk & : Medium & Risk. \\
\hline High Risk & : High risk. & & Low Risk & : Low Risk & \\
\hline
\end{tabular}

Consequence analysis measurement scale according to NA / NZS 4360: 2004 :

Table 1. Levels of risk, according to AS / NZS 4360:2004. 


\section{Results and Discussion}

\subsection{Validity Test.}

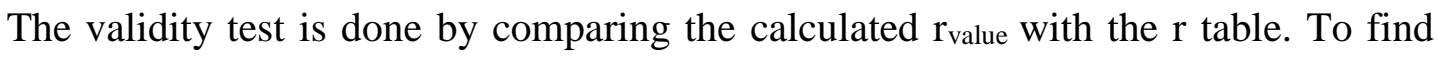
the value of $r$ table with the number of samples $(\mathrm{N})=38,5 \%$ significance in the distribution of the $r_{v a l u e}$ of the statistical table, the $r_{\text {table }}$ value is 0,320 . The results of the calculation of the validity test of the instruments that have been processed using the IBM SPSS Statistic 25 software are summarized in table form to make it easier to choose valid questionnaire.

Table 2. Testing Results validity Instrument.

\begin{tabular}{clccc}
\hline No & \multicolumn{1}{c}{ Variable } & $\mathbf{r}_{\text {count }}$ & $\mathbf{r}_{\text {table }}$ & Information \\
\hline 1 & The worker falls in the excavation of the foundation & 0,526 & 0,320 & Valid \\
2 & The worker's hand is scratched/pinched by the tool & 0,486 & 0,320 & Valid \\
3 & The hand of the worker hit the hammer & 0,457 & 0,320 & Valid \\
4 & The touching thing, not move. & 0,415 & 0,320 & Valid \\
5 & Worker falls from a height. & 0,402 & 0,320 & Valid \\
6 & Steel frame fell (hit the worker) & 0,316 & 0,320 & Invalid \\
7 & Worker's hands/feet were injured while cutting iron & 0,396 & 0,320 & Valid \\
8 & The hollow metal fell on the worker & 0,387 & 0,320 & Valid \\
9 & Worker's hands are pinched/damaged when drilling & 0,328 & 0,320 & Valid \\
10 & Head hit the scaffolding & 0,379 & 0,320 & Valid \\
11 & Scaffolding collapses/collapses (falls on workers) & 0,365 & 0,320 & Valid \\
12 & Work equipment fell on the workers below & 0,345 & 0,320 & Valid \\
13 & Inhalation of dust / respiratory irritation & 0,329 & 0,320 & Valid \\
14 & Hand hit by a ceramic cutting machine & 0,367 & 0,320 & Valid \\
15 & Workers were electrocuted & 0,384 & 0,320 & Valid \\
16 & Exposed to welding flames & 0,343 & 0,320 & Valid \\
17 & Noise/hearing loss & 0,285 & 0,320 & Invalid \\
18 & Wounds when laying pipes & 0,333 & 0,320 & Valid \\
19 & Slipped because the floor was slippery & 0,347 & 0,320 & Valid \\
20 & Workers who are fighting & 0,259 & 0,320 & Invalid \\
\hline
\end{tabular}

Source : Primary data processed.

\subsection{Reliability Test.}

The results of the validity test of a correct questionnaire statement must be tested for safety. $\mathrm{N}$ use-values test results of reliability can be seen in Table 3.

Table 3. Instrument Reliability Test Results.

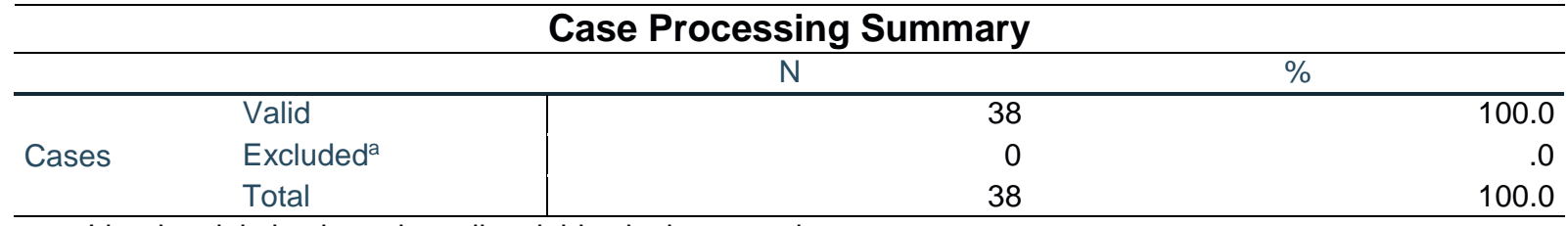

a. Listwise deletion based on all variables in the procedure.

\section{Reliability Statistics}

Cronbach's Alpha $\mathrm{N}$ of Items

$$
0.647
$$

Source : IBM SPSS Statistic 25 Output Results. 
Table 3. that the variables studied had a Cronbach's Alpha above 0,600 so that everything is considered reliable and can be used for the subsequent analysis stage.

\subsection{Data Analyst.}

The analysis is carried out on assessing probability and the impact of risks on aspects of work accidents. The method used in analyzing or assessing risk variables uses a risk index, after which it is entered into the matrix to determine the level of risk.

Table 4. Results Of The Calculation Of The Risk Index.

\begin{tabular}{|c|c|c|c|c|}
\hline No & Risk Event & $\begin{array}{c}\text { Opportunity } \\
\text { Average }\end{array}$ & $\begin{array}{c}\text { Impact } \\
\text { Average }\end{array}$ & $\begin{array}{c}\text { Risk } \\
\text { (Opportunity } \\
\text { x Impact) }\end{array}$ \\
\hline 1 & $\begin{array}{l}\text { Worker falls in the excavation of the } \\
\text { foundation }\end{array}$ & 3 & 3 & 9 \\
\hline 2 & $\begin{array}{l}\text { The worker's hand is scratched/pinched } \\
\text { by the tool }\end{array}$ & 3 & 3 & 9 \\
\hline 3 & The side of the worker hit the hammer & 3 & 4 & 12 \\
\hline 4 & The touching thing, not move. & 4 & 5 & 20 \\
\hline 5 & Worker falls from a height & 2 & 2 & 4 \\
\hline 6 & $\begin{array}{l}\text { Worker's hands/feet were injured while } \\
\text { cutting iron }\end{array}$ & 2 & 4 & 8 \\
\hline 7 & The hollow metal fell on the worker & 2 & 3 & 6 \\
\hline 8 & $\begin{array}{l}\text { Worker's hands are pinched/damaged } \\
\text { when drilling }\end{array}$ & 2 & 3 & 6 \\
\hline 9 & Head hit the scaffolding & 3 & 5 & 15 \\
\hline 10 & $\begin{array}{l}\text { Scaffolding collapses/collapses (falls on } \\
\text { workers) }\end{array}$ & 3 & 3 & 9 \\
\hline 11 & $\begin{array}{l}\text { Work equipment fell on the workers } \\
\text { below }\end{array}$ & 2 & 4 & 8 \\
\hline 12 & Inhalation of dust / respiratory irritation & 3 & 4 & 12 \\
\hline 13 & Hand hit by a ceramic cutting machine & 2 & 3 & 6 \\
\hline 14 & Workers were electrocuted & 1 & 3 & 3 \\
\hline 15 & Exposed to welding flames & 2 & 3 & 6 \\
\hline 16 & Wounds when laying pipes & 3 & 3 & 9 \\
\hline 17 & Slipped because the floor was slippery & 3 & 4 & 12 \\
\hline
\end{tabular}

Source : Primary Data Processed. 
Table 5. Risk Classification Based On The AS/NZS 4360 Risk Matrix.

\begin{tabular}{|c|c|c|c|c|c|}
\hline No & Variabel (Risk Event) & $\begin{array}{l}\text { Opportunity } \\
\text { Average }\end{array}$ & $\begin{array}{c}\text { Impact } \\
\text { Average }\end{array}$ & $\begin{array}{c}\text { Risk } \\
\begin{array}{c}\text { Opportunity } x \\
\text { Impact) }\end{array} \\
\end{array}$ & $\begin{array}{c}\text { Risk of } \\
\text { Matriks }\end{array}$ \\
\hline 1 & $\begin{array}{l}\text { The worker falls in the excavation of } \\
\text { the foundation. }\end{array}$ & 3 & 3 & 9 & Medium \\
\hline 2 & $\begin{array}{l}\text { The worker's hand is scratched/pinched } \\
\text { by the tool. }\end{array}$ & 3 & 3 & 9 & Medium \\
\hline 3 & The side of the worker hit the hammer & 3 & 4 & 12 & High \\
\hline 4 & The touching thing, not move. & 4 & 5 & 20 & Very High \\
\hline 5 & Worker falls from a height & 2 & 2 & 4 & Low \\
\hline 6 & $\begin{array}{l}\text { Worker's hands/feet were injured while } \\
\text { cutting iron }\end{array}$ & 2 & 4 & 8 & Medium \\
\hline 7 & The hollow metal fell on the worker & 2 & 3 & 6 & Medium \\
\hline 8 & $\begin{array}{l}\text { Worker's hands are pinched/damaged } \\
\text { when drilling }\end{array}$ & 2 & 3 & 6 & Medium \\
\hline 9 & Head hit the scaffolding & 3 & 5 & 15 & High \\
\hline 10 & $\begin{array}{l}\text { Scaffolding collapses/collapses (falls on } \\
\text { workers) }\end{array}$ & 3 & 3 & 9 & Medium \\
\hline 11 & $\begin{array}{l}\text { Work equipment fell on the workers } \\
\text { below }\end{array}$ & 2 & 4 & 8 & Medium \\
\hline 12 & Inhalation of dust/respiratory irritation & 3 & 4 & 12 & High \\
\hline 13 & Hand hit by a ceramic cutting machine & 2 & 3 & 6 & Medium \\
\hline 14 & Workers were electrocuted & 1 & 3 & 3 & Low \\
\hline 15 & Exposed to welding flames & 2 & 3 & 6 & Medium \\
\hline 16 & Wounds when laying pipes & 3 & 3 & 9 & Medium \\
\hline 17 & Slipped because the floor was slippery & 3 & 4 & 12 & High \\
\hline
\end{tabular}

Source : Primary Data Processed.

\subsection{Risk Resume Level.}

Of data processing matrix (tenderloin classification) in table 5.1. variable obtained with a level of risk very high in variable touched movable/stumble, the level of high risk obtained four variables, the risk moderate purchased ten variables, and a low risk of acquired two variables. Control to handle each risk as follows :

1. For variables touched by immovable objects/tripping with a very high level of risk (Very High Risk), it is namely utilizing an administrative way which reduces the risk of hazards by making procedures, rules, installation of signs (safety signs), warning signs, training, and selection of contractors. It also required personal protective equipment standards, work, and the obligations agreed by the government through the Ministry of Labor of the Republic of Indonesia.

2. The four high-risk variables (High Risk), OHS risk control using administrative techniques, and Personal Protective Equipment (PPE). 
3. For ten risk variables obtained with moderate risk level (Medium Risk), countermeasures can be done with engineering, administrative, and Uses. Personal Protective Equipment (PPE). Handling it by reducing, funding, overcoming, and transferring risks to other parties such as insurance and other parties that are directly related.

4. For two variables, rustle o obtained with the risk level low (Medium Risk) because Protective Equipment Denvy (PPE) that is in use already meet the standards following the obligations agreed by the government through the Ministry of Labor of the Republic of Indonesia.

\section{Conclusions and Suggestions}

\subsection{Conclusions.}

Based on the results of occupational health and safety (K3) risk measurement in the construction of the Kadiri University LP3M building, it can be concluded as follows :

1. Obtained one variable is categorized as level a very high risk (Very High Risk) is a variable touched objects that do not move or stumble, to the level of high risk (High Risk) obtained four variables, for level risk (Medium Risk) is obtained ten variables and for a low-risk level (Low Risk) 2 variables.

2. Control that can be done from a known risk level is by reducing risk by engineering, administrative, and using Personal Protective Equipment (PPE) that meets standards following the obligations agreed by the government through the Ministry of Manpower of the Republic of Indonesia. To handling it by reducing, funding, overcoming, and transferring risks to other parties such as insurance and other parties that are directly related.

\subsection{Suggestions.}

Based on the above conclusions, it should be done to prevent the risk of work accidents by implementing K3 management rules and implementing strict and enforced sanctions on workers in the field so that work becomes more effective, safe, and unwanted. We recommend that the equipment or support for occupational safety and health (K3) be complete because, at the location, the researchers found incomplete personal protective equipment (PPE). 


\section{References}

[1] Candra A. I. (2017), "PADA PEMBANGUNAN GEDUNG MINI HOSPITAL UNIVERSITAS KADIRI," UKaRsT, vol. 1, no. 1, pp. 27-34.

[2] A.- Indah, "Evaluasi Penerapan Keselamatan Dan Kesehatan Kerja (K3) Pada Proyek Bangunan Gedung Di Kabupaten Cirebon,” J. Tek. Sipil dan Perenc., vol. 19, no. 1, pp. 1-8, 2017, doi: 10.15294/jtsp.v19i1.9492.

[3] P. Proyek and P. Jambuluwuk, "MANAJEMEN RISIKO KESELAMATAN DAN KESEHATAN KERJA ( K3 ) PETITENGET RISK MANAGEMENT OF OCCUPATIONAL HEALTH AND SAFETY ( K3 ) IN THE DEVELOPMENT PROJECTS OF JAMBULUWUK HOTEL \& RESORT MANAJEMEN K3," Spektran, vol. 5, no. 1, pp. 47-55, 2017.

[4] E. Gardjito, A. I. Candra, and Y. Cahyo, "Pengaruh Penambahan Batu Karang Sebagai Substitusi Agregat Halus Dalampembuatan Paving Block," UKaRsT, vol. 2, no. 1, p. 36, 2018, doi: 10.30737/ukarst.v2i1.374.

[5] D. Palloan, "Analisis Risiko Kecelakaan Kerja Pada Proyek Konstruksi Gedung Bertingkat Pada Proyek Konstruksi Gedung Bertingkat Di Kota Makassar," UNHAS, vol. 1, no. 1, pp. 1-8, 2016.

[6] G. E. M. Soputan, B. F. Sompie, R. J. M. Mandagi, D. Pascasarjana, T. Sipil, and U. Sam, "MANAJEMEN RISIKO KESEHATAN DAN KESELAMATAN KERJA ( K3 ) ( Study Kasus Pada Pembangunan Gedung SMA Eben Haezar )," Ilm. Media Eng., vol. 4, no. 4, pp. 229-238, 2014.

[7] F. N. Anwar, I. Farida, and A. Ismail, "ANALISIS MANAJEMEN RISIKO KESEHATAN DAN KESELAMATAN KERJA ( K3 ) PADA PEKERJAAN UPPER STRUCTURE GEDUNG BERTINGKAT ( STUDI KASUS PROYEK SKYLAND CITY - JATINANGOR )," STT GARUT, vol. 13, no. 1, pp. 1-13, 2014.

[8] H. Wahyudiono, S. D. Hartantyo, U. I. Lamongan, and U. Kadiri, "UNIVERSITAS KADIRI,” vol. 1, no. 2, pp. 137-145, 2017.

[9] R. Ningsih, A. R. Azhar, and M. P. A. Paripurno, "Manajemen Risiko Keselamatan dan Kesehatan Kerja ( K3 ) dalam Praktikum Pengelasan ( Studi Kasus : di Welding Centre Politeknik Perkapalan Negeri Surabaya )," Politek. Perkapalan Negeri Surabaya, vol. 01, no. November, pp. 103-108, 2016. 
[10] P. Pemerintah, "Indonesia Higher Education Statistical Year Book 2018," Chem. - A Eur. J., vol. 15, no. 21, pp. 1-7, 2018, doi: 10.1002/chem.200802548.

[11] K. Wall, “The Trouble with Risk Matrices," Harv. Bus. Rev., vol. 87, no. 10, p. 16, 2009.

[12] G. Anggraini, "KAJIAN PUSTAKA (LITERATURE REVIEW,” UNHAS, vol. 2, no. 1984, pp. 1-13, 2015.

[13] S. Choe, F. L. Pe, T. Strategy, and C. Bldg, "Transforming inherent safety risk in the construction Industry: A safety risk generation and control model," Saf. Sci., vol. 124, no. March 2018, p. 104594, 2020, doi: 10.1016/j.ssci.2019.104594.

[14] L. Kraidi, R. Shah, W. Matipa, and F. Borthwick, "Analyzing the Critical Risk Factors Associated with Oil and Gas Pipeline Projects in Iraq," Int. J. Crit. Infrastruct. Prot., 2018, doi: 10.1016/j.ijcip.2018.10.010.

[15] P. N. Sarlinton and S. Pratiwi, Riyanny, "Identifikasi Penerapan K3 Pada Gedung Pemerintah," UNTAN, vol. 1, no. 2, pp. 1-4, 2019.

[16] K. Karyawan, P. T. Haleyora, and P. Pekanbaru, "PENGARUH KESELAMATAN DAN KESEHATAN KERJA (K3) TERHADAP KINERJA KARYAWAN PT. HALEYORA POWERINDO PEKANBARU," JOM FISIP UNRI, vol. 3, no. 2, pp. 1$10,2016$.

[17] G. E. M. Soputan, "Manajemen Risiko Kesehatan dan Keselamatan Kerja (K3) (Study Kasus Pada Pembangunan Gedung SMA Eben Haezar),” J. Ilm. Media Eng., 2014.

[18] Suwinardi, "Manajemen risiko proyek," Orbith, vol. 12, no. manajemen resiko proyek, pp. 145-151, 2016.

[19] S. Al-anbari, A. Khalina, A. Alnuaimi, A. Normariah, and A. Yahya, "Risk assessment of safety and health ( RASH ) for," Process Saf. Environ. Prot., vol. 94, pp. 149-158, 2015, doi: 10.1016/j.psep.2015.01.009.

[20] A. Ridwan, "PROYEK KONSTRUKSI," UKaRsT, vol. 1, no. 1, pp. 74-83, 2017.

[21] G. Rong, W. Sainan, and H. Mengshi, "Underground railway safety analysis and planning strategy: a case of Harbin metro line 1, China," Procedia Eng., vol. 165, pp. 575-582, 2016, doi: 10.1016/j.proeng.2016.11.753.

[22] B. R. Kani, R. J. M. Mandagi, J. P. Rantung, and G. Y. Malingkas, "Keselamatan Dan Kesehatan Kerja Pada Pelaksanaan Proyek Konstruksi (Studi Kasus: Proyek Pt. Trakindo Utama)," J. Sipil Statik, vol. 1, no. 66, pp. 430-433, 2013. 
[23] A. Sofyan, "PENGARUH KESEHATAN DAN KESELAMATAN KERJA (K3) TERHADAP KINERJA KARYAWAN PT. BEKAERT INDONESIA PLANT KARAWANG,” Alumni S-2 MM STIE Tek. Sipil, vol. 2, no. 4, pp. 22-45, 1392.

[24] E. T. Moh, "Kesehatan dan keselamatan kerja laboratorium kesehatan," Setjen Depkes R.I., vol. 3, no. 2, pp. 45-59, 2007.

[25] U. N. Nissa and S. Amalia, "Pengaruh Keselamatan dan Kesehatan Kerja Terhadap Kinerja Karyawan,” J. Ris. Bisnis dan Investasi, vol. 44, no. 3, pp. 89-95, 2017, doi: 10.35697/jrbi.v3i3.946.

[26] K. D. Wall, “THE TROUBLE WITH RISK MATRICES,” Nav. Postgrad. Sch. August, vol. 1, no. November, pp. 1-26, 2014. 